\title{
A Survey of Investors Preference on Stock Market : A Case of Nepal Stock Exchange
}

\author{
Post Raj Pokharel $^{1}$
}

\begin{abstract}
This paper shows investors preference on stock market of Nepal Stock Exchange (NEPSE). The study is based on survey method using structured questionnaire. The results demonstrated that investors were found to have investment interest in secondary market. The reasons for selecting shares are mostly liquidity and high rate of earning. The investors' perception regarding the influencing factors for the investment decision in secondary market of NEPSE is the advice of brokers and then movement of indices. The news in daily newspaper and market sentiments are viewed as least influencing factors for investment decision. Most motivating factors prioratized by respondents were capital gains, then liquidity and then dividend, safety and bonus shares. The motivating factors like tax benefits and rights shares were under least preference by the respondents.
\end{abstract}

Key Terms: Investment, NEPSE stock

JEL Classification: G11, N25

\subsection{Introduction:}

Barber 2011, study motivates on studying the behavior of individual investors mostly stressing that the bulk of research in modern economics has been built on the notion that human beings are rational agents who attempt to maximize wealth while minimizing risk. He cited Grossman and Stiglitz's (1980) study that shows rational expectations model, some investors choose to acquire costly information and others choose to invest passively. Informed, active, investors earn higher pre-cost returns, but, in equilibrium, all investors have the same expected utility. Investment culture can also be stated by the study of Ramakrishna and Krishnudu (2009) on investment behavior of rural investors in their study states that the investment culture among the people of a country is an essential prerequisite for capital formation and the faster growth of an economy. Investment culture refers to the attitudes, perceptions, and willingness of the individuals and institutions in placing their savings in various financial assets, more popularly known as securities. A study on the investors' perceptions and preferences, thus, assumes a greater significance in the formulation of policies for the development and regulation of security markets in general and protection and promotion of small and house-hold investors in particular.

The capital market is used as the main vehicle to mobilize funds for the economic growth of the country. It performs crucial functions like the conversion of savings of the households and institutions into

1 Mr. Pokhrel is Asst. Professor Kathmandu University School of Management (KUSOM), M. Phil. (Tribhuvan University, Finance), Ph.D. Scholar (Pokhara University), Website: postrajpokharel.wordpress.com,E-mail:pr_pokharel@yahoo.com, pr_pokharel@hotmail. com, postraj25@gmail.com, Mobile No.9845331778 
investment, creation of financial assets and development of asset-related products. A well functioning securities market is conducive to the sustained economic growth of any country in the world, Levine and Ross (2008). Nepalese Capital market is one of the slightly growing markets at the current moment. It has grown impressively during the recent years in tune with the global financial markets. The Nepalese Capital Market comprises of two segments, namely, the Primary and the secondary market. The fresh issue of securities takes place in primary market and trading among investors takes place in secondary market. The primary market is the major channel through which the savings of the households are mobilized by the companies directly for investment purposes. It is the centre stage of the capital market that really boosts industrial and financial activities by providing long term funds to the corporate and the government. It infuses new securities, adding volume and wider base of securities in the secondary market. The secondary market affords liquidity to the investment in securities and reflects the general health of the economy.

Modigliani and Miller (1958) theorem establishes that in perfect capital markets (i.e., without taxes, transaction or bankruptcy costs, or asymmetric information) a firm's dividend policy does not affect its value. In this setting, investors can replicate any stream of dividend payments through the purchase and sale of appropriate equities. Miller and Modigliani (1961) hypothesize that such heterogeneity leads to what they termed a "dividend clientele effect": investors naturally sort into equity holding classes based on their dividend payout ratios. According to the dividend clientele hypothesis, firms with high (low) dividend-payout ratios attract investors with low (high) marginal tax rates. In the aggregate, an individual's portfolio dividend yield, i.e., the ratio of dividend income to the value of equity holdings, should decrease with income. Shleifer (2000) assumes that there are two broad types of investors: i) relatively sophisticated or ordinary investors (e .g., individual investors or noise traders), whose time-varying demands for risky assets are not based on optimal forecasts of expected returns; and ii) relatively more sophisticated or smart investors (e .g., institutional investors or arbitrageurs), who respond to optimal forecasts of expected returns. Investors are investing their money with the different objectives that may for the purpose of profit, for the purpose of security of their investment, appreciation and income stability. In Nepal, Nepal Stock Exchange has opened investment avenues to the capitalist or so called investors who can investment in varieties of investment securities like in banks, finance companies, hotels, manufacturing and service. Capital Market is a one of the significant aspect of any financial market. Individual investors represent a vital element for the functioning of capital market. The most crucial challenge faced by the investors is perhaps in the area of taking investment decisions especially to the selection of the companies that gives higher return in the form of capital gain or dividend yield. Investors buy shares specifically for income. "What drives people toward buying or selling stocks" is the major issues for the researcher that supports to analyze the preference behavior of the investors. In Nepal, stock market preference is being the issue to be raised as investors focus mostly goes to Commercial banks. The daily transactions of shares have been highly sensitive to the commercial banks. While looking after the view of the investors in terms of investment purpose, they can be further categorized into Institutional investors, informed investors, big individual investors, amateur investors and absent investors. Essentials of investment refer to why 
A Survey of Investors Preference on Stock Market : A Case of Nepal Stock Exchange

investment, or the need for investment, is required. The investment strategy is a plan, which is created to guide an investor to choose the most appropriate investment portfolio that will help him achieve his financial goals within a particular period of time. An investment strategy usually involves a set of methods, rules, and regulations, and is designed according to the exchange or compromise of the investor's risks and returns.

The study of Schmidt and Spreng (1996) specially focused that better-educated Investors have a more extensive knowledge structure and are more capable of identifying, locating, and assimilating relevant information. Therefore, Investors with a higher education level would be able to search using sources that require more knowledge, such as books, newspapers, or the Internet. Moreover, Investors with higher educational levels may be more realistic about their own ability to invest and more open-minded toward professional service providers. Likewise,

Empirical studies have proved that shares (or equities) are one of the best long-term investments in the financial market place. Share prices can go down as well as up so buying shares is not without risk, but over the long term, they can generate good returns. Shollapur and Kuchanur (2008) on a study on individual investors in selected investment avenues assessed in their research investors strongly agree on the perceptions in the case of bank deposits (80\%) life insurance policies $(65 \%)$. on the other hand $(54 \%)$ disagree on in the case of corporate securities. The perceptual gaps analysis presents certain revelations corporate securities are less preferred; government securities do not provide regular and steady income; investment in insurance policies appreciate in values; bank deposits require more transaction costs etc. there is a need to help investors develop a right perspective of the investment schemes and their attributes.

With reference to the focusing investment pattern in India, the study by Ramprasath and Karthikeyan (2013) has focused on individual investors' behavior towards selection of investments, states that the majority of the investors are giving much importance for the factor "safety". Similarly investment avenues such as Bank deposits, LIC polices and Bullion has been preferred by the individual investors. Similarly the majority of the investors are periodically evaluating the performance of their investment avenues.

This study specially focuses on identifying the choice of investment and the focus of selecting the listed companies with reasons behind the selection criteria. On going through the review of literature it is found that there are number of factors which affect the investment decisions of an individual and this has added more the scope for the research in this area is wide and not conclusive. Some few reviews like: Sanjay (2012) studied the middleclass household's investment behavior and found that the trends of investment by households are not similar in nature and they vary between several financial instruments. The study reveals that amongst other avenues the bank deposits remain the most popular instrument of investment followed by insurance and small saving scheme with maximum number of respondents investing in fixed income bearing option. 
A Survey of Investors Preference on Stock Market : A Case of Nepal Stock Exchange

The study by Chaturvedi and Shruti (2012) studied the saving pattern and investment Preferences of individual household in India found out that most investors preferred bank deposit as the first choice of investment and next to bank deposits small saving schemes constitutes the second choice of investment.

Geetha and Ramesh (2012) studied the relevance of demographic factors in investment decision and reveals that there is significant relationship between the demographic factors such as gender, age, education, occupation, annual income and annual savings with the sources of awareness obtained by the investors.

Rakesh and Shrinivas (2013) with his study on individual investment behavior in mutual funds on 400 investors covering the categories of Executive \& Non-Executives and observed that 185 investors are interested in investing in bank sponsored mutual funds because of security and 126 investors are interested in investing in institutions because of their returns, remaining 89 investors are interested in investing in private sector $\&$ joint venture to maximize their returns and to hedge against risk.

Shaik et al. (2012), examined that the level of importance assumed by the retail equity investors on various investment objectives based on the socio economic variables and selective investment profile factors. With the help of average score analysis with the help of Kruskal Wallis H-Test found out that the investors attach/attract more importance to liquidity, quick gain, capital appreciation and safety in equity investments compared to others. Referring to the different literatures in relation with investors preference on stock market this study primarily focused on analyzing the investors preference on investing to the stocks of listed companies of NEPSE besides the study tries to study (1) the investors choice of investment on the listed companies of NEPSE, (2) the reasons for selecting the particular companies on NEPSE, (3) the motivating factors that influence the investment preference, and (4) the reasons for investment in IPOs.

\section{Methodological aspect}

This study used survey research design and made attempts to collect data from randomly selected respondents by asking individuals about their opinion, attitudes, behavior. This design was suitable for this kind of study because the researcher intended to collect data meant to ascertain facts investment decisions. This kind of research methodology makes use of surveys to solicit investors informed opinion. It is often used to study the general condition of people and organizations as it investigates the behavior and opinion of people usually through questioning them, Cooper and Schindler (2003). The target population of this study was all the investors drawn from NEPSE which are approximately 1 million, http://sebon.gov. $\mathrm{np} /$ publications. The names and addresses of investors from NEPSE were given by the brokerage firms. A simple random sample of one brokerage firm was selected from which 50 individual investors from it were randomly selected targeting one questionnaire each. Random numbers can be obtained using a calculator, a spreadsheet, printed tables of random numbers, or by the more traditional methods of drawing slips of paper from a hat, tossing coins or rolling dice, Neville and Sidney (2004). The respondents were used as convenient as possible. Most of the respondents were chosen who have approached to brokerage firms for 
A Survey of Investors Preference on Stock Market : A Case of Nepal Stock Exchange the purpose of document and suggestion. Primary data were collected using questionnaires which were examined by the researcher personally. The questionnaires were administered to the individual investors personally. This method was appropriate since it encouraged prompt responses from the respondents.

\section{The Results}

The data collected through the survey based questionnaire in this study was sorted and tabulated. The data were analyzed using descriptive statistics using simple frequency and percentage based with the help of SPSS software. All the investors reached provided responses and therefore giving a response rate of $88 \%$.

\section{Table 1: Investors experience in stock market (NEPSE trading)}

\begin{tabular}{|l|l|l|}
\hline Experience in Stock Market & Frequency & Percentage \\
\hline Zero days to 1 Year & 5 & $11 \%$ \\
\hline More than 1 Year but less than 2 Years & 23 & $52 \%$ \\
\hline More than 2 Years but less than 5 Years & 11 & $25 \%$ \\
\hline More than 5 years but less than 10 Years & 1 & $2 \%$ \\
\hline More than 10 Years & 4 & $9 \%$ \\
\hline Total & 44 & $100 \%$ \\
\hline
\end{tabular}

Source: Primary data sheet

The above table 1 presents the investors experience in the stock market of NEPSE. Out of the selected respondents, majority of respondents (23 i.e. 52\%) were having 1 to 2 years experience following by (11 i.e. $25 \%$ ) respondents were having 2 to 5 years experience in NEPSE shares.

Table 2: Investor's Investment portfolio in different companies

\begin{tabular}{|l|l|l|}
\hline Investment Portfolio (Companies) & Frequency & Percentage \\
\hline 1 to 5 & 35 & $80 \%$ \\
\hline 6 to 10 & 5 & $11 \%$ \\
\hline 11 to 20 & 3 & $7 \%$ \\
\hline Above 20 & 1 & $2 \%$ \\
\hline Total & $\mathbf{4 4}$ & $\mathbf{1 0 0 \%}$ \\
\hline
\end{tabular}

Source: Primary data sheet

The table 2 shows the investor's investment portfolio in NEPSE companies. Almost respondents were found investing in 1 to 5 companies i.e. 80\% investors. This result shows that the concept of investment in more companies is increasing in NEPSE.

Table 3: Investors mode of investment

\begin{tabular}{|l|l|l|}
\hline Mode of Investment & Frequency & Percentage \\
\hline Primary Market & 5 & $11 \%$ \\
\hline Secondary Market & 29 & $66 \%$ \\
\hline Both (Primary and Secondary) & 10 & $23 \%$ \\
\hline Total & 44 & $100 \%$ \\
\hline
\end{tabular}

Source: Primary data sheet 
A Survey of Investors Preference on Stock Market : A Case of Nepal Stock Exchange

Table 3 presents the move of investment made by investors. The view of investment of investors as primary and secondary or both has been taken in order to identify the astute trader. Most of the investors (29 out of 44 ) investors were found investment interest only in secondary market and only (10 out of 44) were found having interest of investment in both the primary and secondary market. Least, just 5 out of 44 investors were found having interest in primary market.

Table 4: Investors view on reasons for selecting the stock market (NEPSE)

\begin{tabular}{|l|l|l|}
\hline Reasons for selecting stock market & Frequency & Percentage \\
\hline High rate of earning & 25 & $24 \%$ \\
\hline Liquidity & 35 & $33 \%$ \\
\hline Marketability & 12 & $11 \%$ \\
\hline Value Appreciation & 15 & $14 \%$ \\
\hline Regular income & 5 & $5 \%$ \\
\hline Prestige & 14 & $13 \%$ \\
\hline Not Known & 0 & $0 \%$ \\
\hline Total & 106 & $100 \%$ \\
\hline
\end{tabular}

Source: Primary data sheet

Table 4 shows the investors view on reasons for selecting the particular shares of NEPSE. The views from investors regarding the reasons for selection are found mixed as 33\% of views were under liquidity reason, $24 \%$ were viewed for high rate of earning reason. Least respondents were viewed for regular income i.e. $5 \%$.

Table 5: Investors view on criteria considered while operating in Primary market (NEPSE)

\begin{tabular}{|l|l|l|}
\hline Criterion considered while operating in the Primary Market & Frequency & Percentage \\
\hline Nature and type of product & 21 & $16 \%$ \\
\hline Industry/Sector to which the company belongs & 41 & $32 \%$ \\
\hline Terms of Issues & 23 & $18 \%$ \\
\hline Promoter's track record & 15 & $12 \%$ \\
\hline Board of directors & 5 & $4 \%$ \\
\hline Equity participation by FI & 1 & $1 \%$ \\
\hline Risk factors & 23 & $18 \%$ \\
\hline Total & 129 & $100 \%$ \\
\hline
\end{tabular}

Source: Primary data sheet

The above table 5 shows the use of criteria for the primary investment in stock market by investors. Use of industry/sector is the most i.e. $32 \%$ followed by terms of issue and risk factors i.e. $18 \%$. 
A Survey of Investors Preference on Stock Market : A Case of Nepal Stock Exchange

Table 6: Investors perception on factors influencing the investment decision in secondary market (NEPSE)

\begin{tabular}{|l|l|l|}
\hline Factors influencing the investment decision in secondary market & Frequency & Percentage \\
\hline Change in government policy & 12 & $12 \%$ \\
\hline Advice of brokers & 35 & $34 \%$ \\
\hline Advice of dailies/periodicals & 4 & $4 \%$ \\
\hline Advice of websites & 15 & $15 \%$ \\
\hline Movement of indices & 29 & $28 \%$ \\
\hline Market sentiments & 8 & $8 \%$ \\
\hline Total & 103 & $100 \%$ \\
\hline
\end{tabular}

Source: Primary data sheet

In order to identify the investors perception regarding the influencing factors for the investment decision in secondary market of NEPSE, majority of the investors uses the advice of brokers i.e. 34\% and then movement of indices i.e. $28 \%$. The news in daily newspaper and market sentiments have viewed as least influencing factors for investment decision.

Table 7 Motivating factors in the selection of shares (NEPSE)

\begin{tabular}{|l|l|l|}
\hline Factors influence / motivate in the selection of shares & Frequency & Percentage \\
\hline Dividend & 29 & $16 \%$ \\
\hline Capital gains & 39 & $22 \%$ \\
\hline Bonus shares & 28 & $16 \%$ \\
\hline Rights shares & 15 & $9 \%$ \\
\hline Tax benefits & 3 & $2 \%$ \\
\hline Safety & 29 & $16 \%$ \\
\hline Liquidity & 33 & $19 \%$ \\
\hline Total & 176 & $100 \%$ \\
\hline
\end{tabular}

Source: Primary data sheet

Table 7 shows the motivating factors for selection of shares in NEPSE in which most motivating factors viewed by respondents were Capital gains $22 \%$, liquidity $19 \%$, dividend, safety and bonus shares $16 \%$. The motivating factors like tax benefits and rights shares were under least preference by the respondents.

Table 8: Objectives of investment in shares (NEPSE)

\begin{tabular}{|l|l|l|}
\hline Objectives of Investment & Frequency & Percentage \\
\hline Future security & 28 & $17 \%$ \\
\hline Expected return & 39 & $23 \%$ \\
\hline Liquidity & 33 & $20 \%$ \\
\hline Capital gain & 39 & $23 \%$ \\
\hline Others & 27 & $16 \%$ \\
\hline Total & 166 & $100 \%$ \\
\hline
\end{tabular}

Source: Primary data sheet 
A Survey of Investors Preference on Stock Market : A Case of Nepal Stock Exchange

Table 8 shows the objectives of investment in shares in NEPSE in which equal view of expected return and capital gain was observed i.e. $23 \%$. For the purpose of liquidity i.e. $20 \%$ and future security i.e. $17 \%$ were viewed by the selected investors.

Table 9: Factors of investment (NEPSE)

\begin{tabular}{|l|l|l|}
\hline Factors of investment in company shares & Frequency & Percentage \\
\hline Book value & 11 & $7 \%$ \\
\hline Market value & 43 & $28 \%$ \\
\hline High-low price & 41 & $27 \%$ \\
\hline Earning per share & 20 & $13 \%$ \\
\hline Price earning ratio & 19 & $12 \%$ \\
\hline Market capitalization & 20 & $13 \%$ \\
\hline Total & 154 & $100 \%$ \\
\hline
\end{tabular}

Source: Primary data sheet

Table 9 presents the respondents view on factors of investment in company shares where market value is found in the majority $28 \%$ followed by high-low price factors i.e. $27 \%$. Book value got the least priority only $7 \%$ preference in factors of investment.

Table 10: Reasons for investment in IPOs (NEPSE)

\begin{tabular}{|l|l|l|}
\hline Reasons for Investment in IPOs & Frequency & Percentage \\
\hline Dividend purpose & 29 & $33 \%$ \\
\hline Capital gain & 39 & $44 \%$ \\
\hline Others & 20 & $23 \%$ \\
\hline Total & 88 & $100 \%$ \\
\hline
\end{tabular}

Source: Primary data sheet

Table 10 attempts to present the investors view on reasons for investment in IPOs. Majority of the respondents i.e. $44 \%$ viewed as the capital gain is the main reason for investment in IPO and 33\% view as dividend purpose for the investment in IPO.

\section{Conclusion}

The major conclusion of the study is that investor's preference for investment in listed companies of shares was the liquidity and high rate of return and the influencing factors of investment decision was brokers advice rather than the investors sole decision. 


\section{References}

Barber, B.M. \& Odean, T. (2000). Trading is hazardous to your wealth: the common stock investment performance of individual investors. Journal of Finance, 55, 773-806.

Chaturvedi, M. \& Shruti, K. (2012). Study of saving pattern and investment preferences of individual household in India. International Journal of Research in Commerce \& Management. 3(5), 976-2183.

Cooper et al. (1995), Business Research Methods. NY, McGraw Hill.

Geetha, N. \& Ramesh, M. ( 2012). A study on relevance of demographic factors in investment decisions. International Journal of Financial Management, 1(1), 39-56.

Grossman, S.J. \& Stiglitz, J.E. (1980). On the ompossibility of informationally efficient markets. American Economic Review, 70, 393-408.

Levine \& Ross (2008). Stock market development and economic growth. The world Bank Economic Review, 1012, 323 - 339.

Modigliani, F. \& Miller, M. (1958). The cost of capital, corporation finance and the theory of investment. American Economic Review.

Modigliani, F. \& Miller, M. (1961). Dividend policy, growth, and the valuation of shares. Journal of Business, 1961.

Neville \& Sidney (2004). Simple random sampling techniques, New York: Academic Press.

Rakesh, K. \& Srinivas V.S.M. (2013). Understanding individual investors investment behavior in mutual funds : a study on investors of North Coastal Andhra Pradesh. International Journal of Management, 4(3), 185- 198.

Ramakrishna, R. \& Krishnudu, C. (2009). Investment behavior of rural investors. Finance India, 23(4).

Ramprasath, S \& Karthikeyan, B. (2013). Individual investors' behavior towards select investments, a study with special reference to Kattumannar. The International Journal of Business \& Management, $1(6)$.

Sajay, K.D. (2012). Middle class household's investment behavior: an empirical analysis. Radix International Journal of Banking, Finance and Accounting. 1(9), 2277.

Schmidt, J. B., \& Spreng, R. A. (1996). A proposed model of external consumer information search. Journal of the Academy of Marketing Science, 24, 246-256.

Shollapur, M. R. \& Kuchanur, A. B. (2008). Identifying perceptions and perceptual gaps: a study on investors in selected investment avenues. The Icfai University Journal of Behavioural Finance, 5(2).

Shleifer, A. (2000). Inefficient markets: an introduction to behavioral Finance. Cambridge, UK: Oxford University Press. 